\title{
Non-dominant Primary Motor Cortex
} Repetitive Transcranial Magnetic Stimulation for Moderate to Severe Chronic Pain Caused by Diabetic Neuropathy: Case Series from a
Small Crossover Pilot Study

Liviu Cozma', Laura Dumitrescu ${ }^{1,2}$, Bogdan David $^{3}$, Adriana Nicolau$^{4}$, Mirela Enache ${ }^{4}$, Ruxandra Patrascu4, Bogdan Ovidiu Popescu ${ }^{1,2,5}$

\begin{abstract}
Introduction: Repetitive transcranial magnetic stimulation (rTMS) is a relatively new therapeutic technique with an excellent safety profile but mixed results concerning neuropathic pain. Further studies are needed in order to determine the optimal stimulation protocol. Methods: Three patients suffering from moderate to severe chronic pain caused by diabetic neuropathy underwent high frequency $(10 \mathrm{~Hz})$ rTMS of the primary motor cortex corresponding to the non-dominant hand area. We performed 4 sham sessions, followed, after 3 days of washout, by another 4 sessions of active stimulation. Pain levels were measured using a daily pain diary throughout the entire study period. Results: Moderate to substantial analgesia was noted after stimulation in the first two patients. Pain reduction reached $61 \%$ from baseline two weeks after start of active stimulation in the first patient and was still significant (45\%) a week later. In the second patient pain decreased by $58 \%$ from baseline two weeks after start of active stimulation and reached a $72 \%$ decrease one week later. No benefits were noted in the third patient. Conclusion: High frequency rTMS of the primary motor cortex corresponding to the non-dominant hand area shows promise in alleviating chronic pain caused by diabetic neuropathy.
\end{abstract}

Keywords: repetitive transcranial magnetic stimulation, rTMS, chronic pain, diabetic neuropathy

\section{Rezumat}

Introducere: Stimularea magnetică repetitivă transcraniană (rTMS) este o tehnică terapeutică relativ nouă cu un profil de siguranță excelent, dar cu rezultate neconcludente în ceea ce privește durerea neuropată. Aprofundarea cercetării este necesară pentru determinarea protocolului optim de stimulare. Metode: Trei pacienți cu durere cronică moderat-severă cauzată de neuropatia diabetică au efectuat rTMS cu frecvență înaltă la nivelul cortexului motor primar corespunzând regiunii mâinii non-dominante. Au fost realizate 4 ședințe de stimulare falsă, urmate, după

${ }^{1}$ Second Department of Neurology, CDPC, Colentina Clinical Hospital, Bucharest, Romania

2 "Carol Davila" University of Medicine and Pharmacy, Bucharest, Romania

${ }^{3}$ Department of Neurosurgery, Bagdasar Arseni Emergency Clinical Hospital, Bucharest, Romania

${ }^{4}$ Department of Internal Medicine, CDPC, Colentina Clinical Hospital, Bucharest, Romania

${ }^{5}$ Department of Molecular Medicine, „Victor Babes" National Institute of Pathology, Bucharest, Romania

\section{Corresponding author.}

Bogdan Ovidiu Popescu, Department of Neurology, Colentina Clinical Hospital, Bucharest, Romania.

E-mail: bogdan_ovidiu_popescu@yahoo.com 
Non-dominant Primary Motor Cortex Repetitive Transcranial Magnetic Stimulation for Moderate to Severe Chronic Pain

3 zile de washout, de încă 4 ședințe de stimulare activă. Durerea a fost măsurată utilizând un jurnal zilnic al durerii completat pe întreaga perioadă de studiu. Rezultate: Primii doi pacienți au beneficiat de o analgezie moderată sau chiar substanțială. Pentru primul pacient a fost înregistrată o scădere cu $67 \%$ a durerii după două săptămâni de la începutul stimulării active, menținută la un nivel semnificativ (45\%) o săptămână mai târziu. Durerea celui de-al doilea pacient a scăzut cu 58\% la două săptămâni de la începutul stimulării active și a ajuns până la 72\% după încă o săptămână. Nu au existat beneficii la al treilea pacient. Concluzii: Stimularea magnetică transcraniană repetitivă cu frecvență înaltă a cortexului motor primar corespunzând regiunii mâinii non-dominante pare promițătoare în ameliorarea semnificativă a durerii cronice cauzate de neuropatia diabetică.

Cuvinte cheie: stimulare magnetică transcraniană repetitivă, durere cronică, neuropatie diabetică

\section{INTRODUCTION}

Repetitive transcranial magnetic stimulation (rTMS) is a relatively new therapeutic and diagnostic technique that uses non-invasive neuromodulation and has an excellent safety profile ${ }^{1}$. According to recent EAN guidelines on central neurostimulation in chronic pain conditions there is only week evidence for primary motor cortex rTMS in neuropathic pain ${ }^{2}$, while other guidelines on rTMS state a definite analgesic effect of high frequency rTMS of the primary motor cortex contralateral to pain site in neuropathic pain ${ }^{3}$. No consensus exists on the optimal stimulation protocol and procedures vary greatly across studies. Confounding factors also arise from heterogeneous study populations, most of the studies having mixed patients with different causes of neuropathic pain. Patients suffering from chronic pain caused by diabetic neuropathy could benefit from a technique with a safety profile such as that of rTMS since multiple complications and comorbidities expose them to adverse events related to polypharmacy ${ }^{4}$.

\section{METHODS}

Resources. This study was organized by Colentina Clinical Hospital between 2014 and 2015 as part of the "Colentina - Dezvoltare Pavilion Cercetare" Project (i.e. CDPC Project, "Colentina - Research Pavilion Developement" Project). The infrastructure and consumables required by the study protocol are available mostly via the above mentioned project but also via the routine clinical functioning of Colentina Clinical Hospital.

Study Design. We performed a small interventional single arm crossover pilot study on 3 patients with moderate to severe chronic pain related to diabetic neuropathy. The intervention consisted of sham and active high frequency rTMS applied to the primary motor cortex corresponding to the non-dominant hand area. Our main objective was to assess the short term analgesia of rTMS according to the IMMPACT consensus: non-significant $(\leq 15 \%)$, minimal $(\geq 15 \%)$, moderate $(\geq 30 \%)$ or substantial ( $\geq 50 \%)$. Secondary objectives included assessment of tolerability, unilateral vs. bilateral analgesia with unilateral stimulation, lower limb pain reduction with stimulation of the hand cortex and the relationship between pain levels and other aspects of daily living in the studied population.

Inclusion criteria comprised of documented diabetic neuropathy responsible for moderate to severe chronic pain for at least the last 6 months (moderate to severe pain was defined as a score of at least 4 on the Numerical Pain Rating Scale - NPRS), stable pain medication in the month prior to stimulation and written informed consent. Exclusion criteria were the existence of other causes of pain other than diabetes mellitus, electric implants in the body, metallic implants in the cervicocranial area or a medical history of epileptic seizures, large stroke, cerebral tumors, major neurocognitive disorder or psychiatric diseases.

The patients that met all of the inclusion criteria and had no exclusion criterion were accepted in the study and went on to complete a daily pain diary. They noted the maximum level of pain in the last 12 hours two times a day (in the morning and in the evening) using the NPRS, painkiller use, quality and duration of sleep, adverse events and other observations. After completing this pain diary for one week those with a NPRS average score of at least 4/10 underwent a baseline evaluation that consisted of a neurological examination and questionnaires such as NPRS and douleur neuropatique en 4 questions (DN4). They were then assigned to 4 sham stimulation sessions ( 1 per day) followed by 3 days of washout, after which they crossed over to 4 sessions of active stimulation (1 per day). Multiple evaluation visits were planned: first evaluation visit before the first active procedure ( 7 days after baseline), second evaluation visit 14 days after baseline, as well as an end of study evaluation visit 28 days after baseline. All of these consisted of neurological examination and multiple questionnaires such as NPRS, DN4 and Patients' 
Global Impression of Change (PGIC). The patients continued to keep a daily pain diary throughout the entire study period.

Stimulation description. The rTMS device used in the study was MAGPRO R30 (MagVenture, Denmark). The machine produces biphasic waves with standard pulse mode and a maximal active pulse width of 280 mcs. We used a circular coil (MFC-125 Circular, static fluid cooling, transducer diameter $140.5 \mathrm{~mm}$, coil inner diameter $35 \mathrm{~mm}$, coil outer diameter $121 \mathrm{~mm}$, number of windings 13, pulses before warm-up 2000 at 1 pulse per second, $75 \%$ of maximum power and $20^{\circ} \mathrm{C}$ room temperature, maximal initial magnetic field gradient 34 kT/s, MagVenture, Denmark. The MAGPRO R30 device was equipped with an adjustable support arm for the coil thus permitting the coil position to be fixed during the rTMS procedure.

In both active and sham procedures the circular coil was placed tangentially to the scalp area that was considered to correspond to the cortical representation of the hand in the non-dominant primary motor area. The coil was then oriented so that the induced electrical currents would flow approximately perpendicular to the central sulcus, at a $45^{\circ}$ angle from the mid-sagittal line. A single magnetic pulse at $60 \%$ of the maximum power produced by the device (or at the previously estimated motor threshold) was repeatedly applied until the hand motor cortex was localized by a visible muscle contraction in the contralateral hand. Then the clinically estimated motor threshold was determined, defined as the lowest power at which 5 out of 10 pulses produce a visible muscle contraction.

In the active procedure ten trains of 200 pulses at a power of $80 \%$ of the clinically estimated motor threshold with a frequency of $10 \mathrm{~Hz}$ and interbrain interval of 40 seconds were applied with the circular coil tangentially placed on the scalp region corresponding to the non-dominant primary motor hand as described above. In the sham procedure all stimulation parameters were identical but power was reduced to $20 \%$ of the clinically estimated motor threshold and the coil was placed in a perpendicular position on the scalp area corresponding to the non-dominant primary motor hand. Both types of sessions lasted 10 minutes each and a total number of 2000 pulses were applied per procedure.

Blinding. Both the patients and the evaluating neurologist were blinded in regard to sham versus active procedures. The blinding procedure for patients was not ideal. Even though sham stimulation power was kept to $20 \%$ so as to maintain similar auditory stimuli, the coil had to be positioned perpendicularly to the scalp to keep unwanted cortical stimulation to a minimum. This lead to differences in tactile stimuli between sham and active procedures. Patients were asked after each session what type of stimulation they underwent. Since all sham procedures were performed before crossing over to active stimulation, all 3 patients thought they underwent active stimulation.

\section{RESULTS}

Analysis of our main objective (i.e. reduction in pain as per IMMPACT consensus) was assessed using averages of NPRS scores from the pain diary. As such, an average pain score was noted at baseline (B, the week prior to first sham procedure), first evaluation visit (E1, from first sham procedure to first active procedure, days 0-7 from baseline), second evaluation visit (E2, days 7-14 after baseline), first follow-up (F1, days 14-21 after baseline) and second follow-up which marks the end of study evaluation visit (F2, days 21-28 after baseline). These are noted in Table 1.

First patient was a 51-year-old woman that started from a NPRS score of 8.29. Sham stimulation lead to a $37.45 \%$ decrease in pain to a 5.21 NPRS score, while after active stimulation the total decrease in pain reached $44.05 \%$ from baseline. Further analgesia was noted at F1 when the patient reported a $61.58 \%$ improvement in pain, maintained at a significant $45.97 \%$ at F2. We would also like to note a decrease in DN4 score from 9 to only 2 at $\mathrm{F} 2$ and a decrease in painkiller use from 8 doses per week before stimulation to 1 and 2 per week at F1 and F2. There were no important adverse events throughout the entire protocol, the patient having noted only mild paresthesia at the stimulation site (right parietal scalp area) during sessions 3 to 8, and few myoclonic jerks of the inferior eye-lid during the $6^{\text {th }}$ and $7^{\text {th }}$ procedures.

Second patient was a 64 -year-old man with a 6.12 NPRS baseline score that decreased with $46.68 \%$ to a 3.21 score after sham stimulation. Paradoxically, after active stimulation pain levels increased to $21.04 \%$ higher than baseline, but markedly decreased at F1 (55.66\% reduction from baseline) and continued to further decrease at F2 (72.27\% from baseline). The substantial increase in pain observed at E2 appeared in the morning prior to the first active procedure, before actual stimulation began. As such, this increase might be related to external factors, and not to the procedure itself since a substantial reduction in pain was noted at both $\mathrm{F} 1$ and $\mathrm{F} 2$. He reported mild dizziness for a few minutes after the $1^{\text {st }}$ procedure and intermittent right calf paresthesia during and in the minutes after the $2^{\text {nd }}$ 
Non-dominant Primary Motor Cortex Repetitive Transcranial Magnetic Stimulation for Moderate to Severe Chronic Pain

Table 1. Results in pain reduction after rTMS

\begin{tabular}{|c|c|c|c|c|c|c|c|c|}
\hline Patient no. & Age (y) & Sex & NPRS & B & E1 & E2 & F1 & F2 \\
\hline \multirow{2}{*}{$7^{\text {st }}$ patient } & \multirow{2}{*}{51} & \multirow{2}{*}{ W } & NPRS score & 8.29 & 5.21 & 4.66 & 3.2 & 4.5 \\
\hline & & & NPRS change (\%) & - & $-36 \%$ & $-43 \%$ & $-61 \%$ & $-45 \%$ \\
\hline \multirow{2}{*}{$2^{\text {nd }}$ patient } & \multirow{2}{*}{64} & \multirow{2}{*}{ M } & NPRS score & 6.12 & 3.21 & 7.22 & 2.85 & 1.64 \\
\hline & & & NPRS change $(\%)$ & - & $-47 \%$ & $+21 \%$ & $-58 \%$ & $-72 \%$ \\
\hline \multirow{2}{*}{$3^{\text {rd }}$ patient } & \multirow{2}{*}{84} & \multirow{2}{*}{ M } & NPRS score & 4.78 & 4.675 & 3.645 & 6.495 & 5.96 \\
\hline & & & NPRS change (\%) & - & $+4 \%$ & $-16 \%$ & $+43 \%$ & $+29 \%$ \\
\hline
\end{tabular}

procedure. A few myoclonic jerks in the right hemiface were also noted during the $5^{\text {th }}$ and $6^{\text {th }}$ procedures but stimulation was well tolerated, without major discomfort reported by the patient.

Third patient, a 84-year-old man, started from a NPRS baseline score of 4.78. Pain increased with $3.83 \%$ after sham stimulation. Active stimulation lead to a minimal $16.08 \%$ decrease in pain from baseline, but at first and second follow-up visits a $42.67 \%$ and $28.99 \%$ pain increase from baseline was noted. No adverse events were reported throughout the entire study period.

Neither the second nor the third patient made any significant changes in pain medication throughout the study period.

\section{CONCLUSION}

The results of high frequency rTMS in 3 patients with moderate to severe chronic pain related to diabetic neuropathy showed mixed results but pain reduction reached a moderate to substantial level as per the IMMPACT consensus in two patients that was still present 18 days after last active stimulation session. Even though a large placebo effect was noted, a significant and persistent pain decrease was obtained after active stimulation. When present, pain reduction occurred in

\section{References}

1. Rossi S, Hallett M, Rossini PM, Pascual-Leone A, Safety of TMSCG. Safety, ethical considerations, and application guidelines for the use of transcranial magnetic stimulation in clinical practice and research. Clinical neurophysiology: official journal of the International Federation of Clinical Neurophysiology. 2009;120(12):2008-39.

2. Cruccu G, Garcia-Larrea L, Hansson P, Keindl M, Lefaucheur JP, Paulus W, et al. EAN guidelines on central neurostimulation therapy in chronic pain conditions. European journal of neurology. 2016;23(10):1489-99.

3. Lefaucheur JP, Andre-Obadia N, Antal A, Ayache SS, Baeken C, Benninger $\mathrm{DH}$, et al. Evidence-based guidelines on the therapeutic use of repetitive transcranial magnetic stimulation (rTMS). all limbs, not only in the hand corresponding to the stimulated cortex. As such, unilateral hand rTMS can lead to bilateral as well as lower limb analgesia. rTMS also lead to a significant reduction in painkiller use in one patient. Factors that could explain the difference in responders versus non-responders are younger age (51 and 64 vs. 84 years) as well as a more severe baseline pain (a score of 8.29 and 6.12 vs. 4.78 on the NPRS). The analgesic effects of primary motor cortex stimulation seem to be related to modulation of cortical circuits activating descending inhibitory pain control systems involving endogenous opioids through the periaqueductal gray matter (6). Age could induce certain anatomical and physiological changes that may diminish rTMS efficacy by affecting the integrity of these circuits, possibly leading to a decrease in endogenous opioids. Lastly, primary motor cortex high frequency rTMS had a very good safety profile, being well tolerated by all patients, with only minor periprocedural adverse events in two patients. The results of this pilot study serve as support for future research projects on rTMS at Colentina Clinical Hospital - CDPC.

Disclosure: The results reported in this study were first presented as poster on display at the $3^{\text {rd }}$ Congress of the European Academy of Neurology in June 2017.

Clinical neurophysiology : official journal of the International Federation of Clinical Neurophysiology. 2014;125(11):2150-206.

4. Peron EP, Ogbonna KC, Donohoe KL. Antidiabetic medications and polypharmacy. Clinics in geriatric medicine. 2015;31(1):1727, vii.

5. Dworkin RH, Turk DC, Wyrwich KW, Beaton D, Cleeland CS, Farrar JT, et al. Interpreting the clinical importance of treatment outcomes in chronic pain clinical trials: IMMPACT recommendations. The journal of pain: official journal of the American Pain Society. 2008;9(2):105-21

6. de Andrade DC, Mhalla A, Adam F, Texeira MJ, Bouhassira D. Neuropharmacological basis of rTMS-induced analgesia: the role of endogenous opioids. Pain. 2011;152(2):320-6. 